\title{
A Case of Foreign Body Aspiration Diagnosed in Early Adulthood
}

\section{Genç Erişkin Dönemde Tanı Konulan Yabancı Cisim Aspirasyon Olgusu}

Mustafa Çörtük', Elif Tanrıverdi², Binnaz Zeynep Yıldırım², Kenan Abbaslı², Mehmet Akif Özgül2, Erdoğan Çetinkaya²

\section{Abstract}

Foreign body aspiration is usually seen in childhood mostly under the age of three. Aspiration in adults is rare, except for those with neuropsychiatric disorders and there is almost always a suspicious history for aspiration. Most cases are admitted to hospital early and delayed diagnosis is rare. Herein, we report a 30 -year-old male case who was repeatedly treated for pneumonia and dyspnea for the past 20 years. In his recent hospitalization, he was diagnosed and treated as foreign body aspiration. We present this case, as there was no history of aspiration and it was finally diagnosed in the early adulthood.

Key words: Foreign Bodies, lung, young adult, bronchiectasis.

\section{Özet}

Hava yollarına yabancı cisim aspire edilmesi daha çok çocukluk döneminde ve genellikle de üç yaş alıında görülmektedir. Nöropsikiyatrik hastalar dışında erişkin yaşlardaki aspirasyon hem daha nadirdir, hem de hastanın anamnezinde aspirasyon şüphesi bulunur. Çoğu olguda aspirasyon sonrası erken dönemde hastane başvurusu vardır ve geç saptanan olgular nadirdir. Sunulan olgu, tekrarlayan pnömoni ve nefes darlığı nedeniyle 20 yıldır tekrarlayan hastane başvurusu olan 30 yaşında erkektir. Son başvurusunda kliniğimizce yabancı cisim aspirasyonu tanısı konmuş ve tedavisi yapılmıştır. Aspirasyon anamnezi olmayan ve ancak genç erişkin dönemde tanı koyulabilen bir olgu olması nedeniyle sunuldu.

Anahtar Sözcükler: Yabancı cisimler, akciğer, genç erişkin, bronşektazi.
Foreign body aspiration is more common in children than adults (1). Symptoms may vary depending on the size and location of the foreign body. Complete obstruction of the major airways may cause acute respiratory failure and asphyxia, whereas cough, hemoptysis, and dyspnea are seen in distally located cases (2). A history of aspiration can almost always be obtained in adult patients, except for those with mental retardation or metal confusion (1). Therefore, patients suspected for aspiration often refer early to the hospital. Herein, we present a case of foreign body aspiration diagnosed 20 years later, despite recurring symptoms.

'Department of Chest Diseases, Karabük University Faculty of

Medicine, Karabük, Turkey

'Karabük Üniversitesi Tıp Fakültesi, Göğüs Hastalıkları Ana Bilim Dalı, Karabük

${ }^{2}$ Department of Chest Diseases, Yedikule Chest Diseases and Tho- $\quad{ }^{2}$ Yedikule Göğüs Hastalıkları ve Göğüs Cerrahisi Eğitim ve racic Surgery Training and Research Hospital, İstanbul, Turkey

Submitted (Başvuru tarihi): 12.10.2015 Accepted (Kabul tarihi): 10.12.2015

Correspondence (iletişim): Mustafa Çörtük, Department of Chest Diseases, Karabük University Faculty of

Medicine, Karabük, Turkey

e-mail:mcortuk@yahoo.com 


\section{CASE}

A 30-year-old male patient was admitted to our clinic with fever, cough, sputum, and hemoptysis for one week. His medical history revealed recurrent cough and dyspnea for the past 20 years. He was occasionally treated for bronchitis with inhaler bronchodilators. He was treated for pneumonia four to five times, but was never hospitalized. Neither the patient nor his mother reported a history of aspiration. He did not suffer from any psychiatric disease or mental retardation. He had previously worked with his father who was an electrical technician. Vital signs were as follows: TA: $100 / 60 \mathrm{mmHg}$ with a pulse of $100 \mathrm{bpm}, \mathrm{T}: 38^{\circ} \mathrm{C}$, and $\mathrm{SpO}_{2}: 98 \%$ in room air. Physical examination findings were normal except for reduced respiratory sounds and crackles in the right lower zone. He had a white blood count of $14,810 / \mathrm{ml}$, hemoglobin: $12.2 \mathrm{gr} / \mathrm{dL}$, platelet: $244,000 / \mu \mathrm{L}$, and C-reactive protein level was $68.1 \mathrm{mg} / \mathrm{l}$. Other laboratory findings were normal. Plain chest $X$-ray showed a right paracardiac infiltration (Figure 1). Pneumonia and bronchiectasis of the right lower lobe was seen in computed tomography, as well as a hyperdense formation in the right lower lobe bronchus (Figure 2). The patient was treated with cefuroxime axetil $750 \mathrm{mg}$ tid and clarithromycin 500 bid. Fever relieved within 24 hours. Rigid bronchoscopy (Karl Storz Instruments, Germany) was performed under intravenous anesthesia due to endobronchial formation in the CT. A foreign body totally obliterating the right lower lobe bronchus was seen (Figure 3). A green, plastic, screw-like object was removed and purulent secretion was aspired. After five days of intravenous treatment, the patient was discharged with oral treatment.

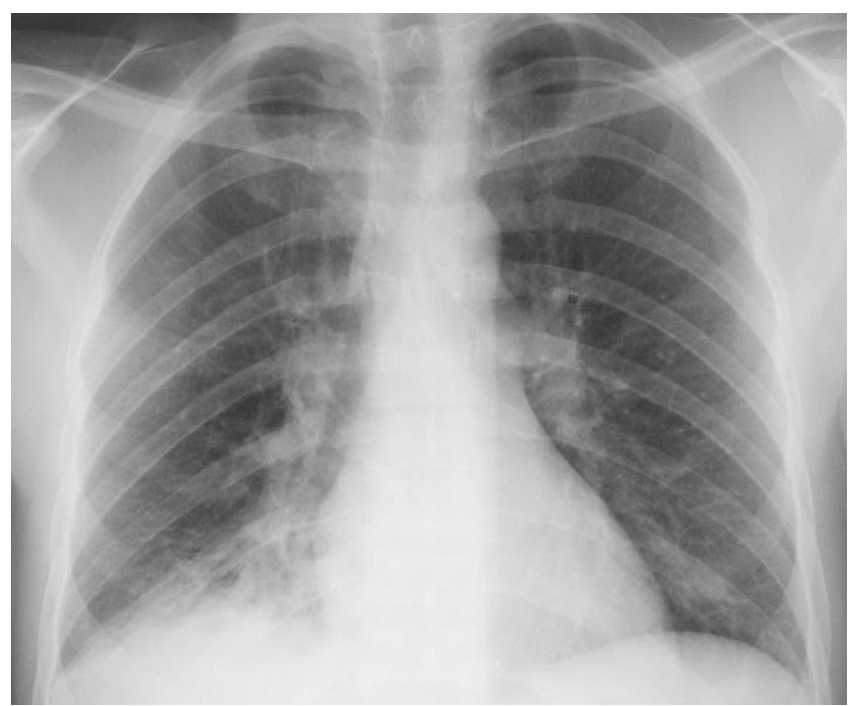

Figure $1 a, b, c:$ Irregular consolidation in the right lower lung zone on chest radiography

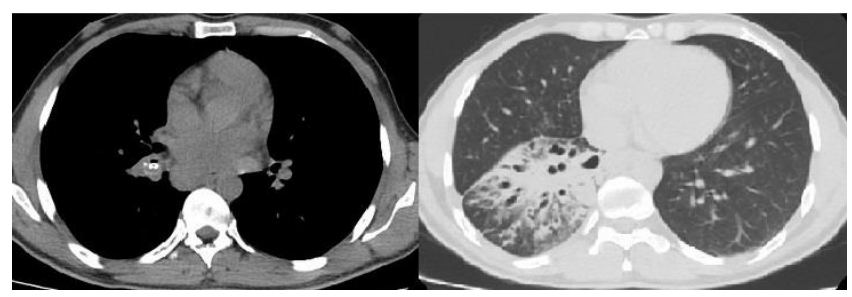

Figure 2: Calcification in the right lower lobe bronchi and pneumonic area in the right lower lobe on computerized tomography

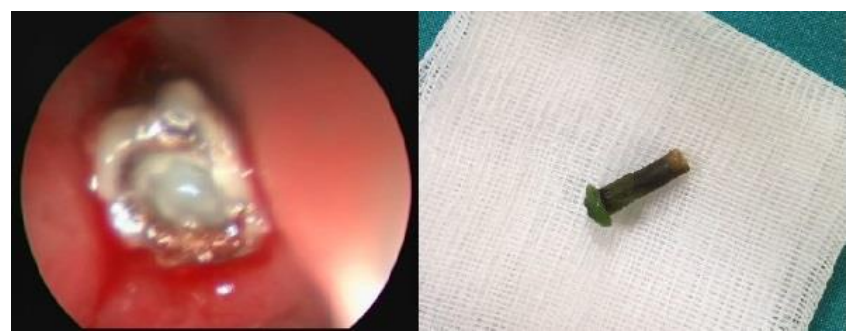

Figure 3: View of the foreign body bronchoscopically and after extraction

\section{DISCUSSION}

Several studies have shown that foreign body aspiration is more common in childhood, compared to the adulthood (1). It is usually seen in children under the age of three (3). It is rare in adults, except for patients with mental retardation and neuropsychriatric diseases (4).

Adults without neuropsychiatric diseases almost always refer to hospital early after aspiration. While in a study performed by Gürsu et al. (5) the latest referral was reported as four years, while in another study the median delay in referral was found to be $40.3 \pm 87$ days (1). Our case was exceptional in both the start and hence probable aspiration time of 10 years of age and in being undiagnosed for 20 years.

In late-diagnosed aspiration cases in adults, the foreign body is usually located distal to the trachea and main bronchi, and, thus, most common symptoms are recurrent infections, cough, and dyspnea (2). Our case also presented with this classical triad. In delayed cases, suspicion is the most important step towards diagnosis, since there is no history of aspiration. In our case, chest $X$-ray revealed non-specific findings, except pneumonic infiltration. Since the patient had a history of recurrent symptoms, thoracic $\mathrm{CT}$ was performed and bronchoscopy was planned due to the calcified endobronchial formation seen in the right lower lobe.

Flexible bronchoscopy is commonly used in the extraction of foreign bodies, since it does not require general anesthesia (6). However, in delayed cases, similar to our case, granulation tissue around the foreign body and bronchiectasis distal to the obstruction may occur (7). In our case, 
the foreign body was extracted using rigid bronchoscopy, since there was a risk of hemorrhage which might require intervention. No significant hemorrhage or complication occurred during bronchoscopy; however, an abundant amount of purulent secretion was aspired.

In conclusion, foreign body aspiration should be considered in cases of recurrent pneumonia and cough, irrespective of the duration and a careful radiological examination should be performed. In case of suspicious findings, diagnosis and treatment should be preferably achieved using rigid bronchoscopy.

\section{CONFLICTS OF INTEREST}

None declared.

\section{AUTHOR CONTRIBUTIONS}

Concept - M.Ç., E.T., B.Z.Y., K.A., M.A.Ö., E.Ç.; Planning and Design - M.Ç., E.T., B.Z.Y., K.A., M.A.Ö., E.Ç.; Supervision - M.Ç., E.T., B.Z.Y., K.A., M.A.Ö., E.Ç.; Funding -; Materials -; Data Collection and/or Processing - M.Ç., E.Ç., E.T.; Analysis and/or Interpretation - M.Ç., B.Z.Y., E.Ç.; Literature Review - M.Ç., B.Z.Y., E.Ç.; Writing - M.Ç., B.Z.Y., E.Ç.; Critical Review - M.Ç., E.Ç.

\section{YAZAR KATKILARI}

Fikir - M.Ç., E.T., B.Z.Y., K.A., M.A.Ö., E.Ç.; Tasarım ve Dizayn - M.Ç., E.T., B.Z.Y., K.A., M.A.Ö., E.Ç.; Denetleme - M.Ç., E.T., B.Z.Y., K.A., M.A.Ö., E.Ç.; Kaynaklar -; Malzemeler -; Veri Toplama ve/veya İşleme - M.Ç., E.Ç., E.T.; Analiz ve/veya Yorum - M.Ç., B.Z.Y., E.Ç.;
Literatür Taraması - M.Ç., B.Z.Y., E.Ç.; Yazıyı Yazan M.Ç., B.Z.Y., E.Ç.; Eleştirel İnceleme - M.Ç., E.Ç.

\section{REFERENCES}

1. Baharloo F, Veyckemans F, Francis C, Biettlot MP, Rodenstein DO. Tracheobronchial foreign bodies: presentation and management in children and adults. Chest 1999; 1 15:1357-62. [CrossRef]

2. Özdemir C, Sökücü SN, Karasulu L, Büyükkale S, Dalar L. Foreign body aspiration in adult: analysis of 28 cases. Eurasian J Pulmonol 2015; 17:29-34.

3. Mu L, He P, Sun D. Inhalation of foreign bodies in Chinese children: a review of 400 cases. Laryngoscope $1991 ; 101: 657-60$. [CrossRef]

4. Mise K, Savicevic AJ, Pavlov N, Jankovic S. Removal of tracheobronchial foreign bodies in adults using flexible bronchoscopy: experience 1995-2006. Surg Endosc 2009; 23:1360-4. [CrossRef]

5. Gürsu S, Sırmalı M, Gezer S, Fındık G, Türüt H, Aydın E, et al. Tracheobronchial foreign body aspirations in adults. Türk Göğüs Kalp Damar Cerrahisi Dergisi 2006; 14:3841.

6. Donado Una JR, de Miguel Poch E, Casado Lopez ME, Alfaro Abreu JJ. Fiberoptic bronchoscopy in extraction of tracheo-bronchial foreign bodies in adults. Arch Bronchopneumol 1998; 34:76-81.

7. Mahmoud M, Imam S, Patel H, King M. Foreign body aspiration of a dental bridge in the left main stem bronchus. Case Rep Med 2012; 2012:798163. [CrossRef] 